\title{
3: 89239364-89613974
}

National Cancer Institute

\section{Source}

National Cancer Institute. 3: 89239364-89613974. NCI Thesaurus. Code C42188.

Physical location of EPHA3_Gene 